\title{
Pembelajaran Literasi Sains Melalui Pemanfaatan Lingkungan
}

\author{
Reny Kristyowati, Agung Purwanto \\ renykristyowati_pd17s2@mahasiswa.unj.ac.id, agungpurwanto@unj.ac.id \\ Program Pascasarjana Pendidikan Dasar Universitas Negeri Jakarta
}

Scientific Literacy Learning Through Environmental Use

\begin{abstract}
The development of science and technology that caused by $21^{\text {st }}$ century development, requires a globally qualified, reliable, and competitive human resources. One of the skills required in $21^{\text {st }}$ century is scientific literacy. Scientific literacy is a skill to use knowledge, identify question, and take conclusion based of evidences for understanding and making decision about nature and changes done to nature by human activities. Scientific literacy in schools can be created and developed by environment utilization. Students observe and do simple scientific activities, they can directly interact and utilize the environment as learning material. By directly learning and observing in nature, scientific literacy learning can be optimalized. The aim of this research are to understand the implementation of scientific literacy learning by utilizing environment and knowing environment's benefits in developing students' scientific literacy skill. The methods used are literature review by analyzing sources related to this research. The results found by conducting a literature study showing that by utilizing the environment in scientific literacy learning, student learning outcomes increased. Students are active in learning activities and better understand the scientific literacy learning because it is close to the surrounding environment. It can be concluded that the use of the environment is appropriate for scientific literacy learning.
\end{abstract}

Keywords: Scientific Literacy, Learning, Environment

Article Info

Revised date: 3 Mei 2019

Accepted date: 21 Mei 2019

\section{PENDAHULUAN}

Abad 21 menyebabkan perkembangan yang sangat cepat di berbagai aspek kehidupan manusia salah satunya adalah ilmu pengetahuan dan teknologi (IPTEK). Perkembangan ilmu pengetahuan dan teknologi membawa pengaruh terhadap aspek pendidikan dunia. Hal ini menyebabkan berbagai negara bersaing untuk meningkatkan kualitas sumber daya manusianya (SDM). Sumber daya manusia yang dibutuhkan dalam era abad 21 adalah sumber daya manusia yang berkualitas, handal dan mampu bersaing secara global baik dari segi pemikiran, keahlian, maupun keterampilan. Untuk dapat menciptakan suatu sumber daya manusia yang handal dan berkualitas, pendidikan memiliki peranan penting dalam menciptakan generasi penerus bangsa yang mampu berkompetisi di dunia internasional karena pendidikan memiliki peranan yang sangat besar dalam menciptakan kader bangsa.

Pembelajaran di sekolah melalui pembelajaran IPA diharapkan dapat mengembangkan kemampuan peserta didik dalam menghadapi kemajuan IPTEK melalui pembelajaran literasi sains. Literasi sains menurut Firman dalam Dityawiyana (2016) adalah kemampuan menggunakan pengetahuan, mengidentifikasi pertanyaan, dan menarik kesimpulan berdasarkan bukti-bukti dalam rangka memahami serta membuat keputusan berkenaan dengan alam dan perubahan yang dilakukan terhadap alam melalui aktivitas manusia.

Berdasarkan hasil studi PISA terhadap literasi sains yang dilakukan setiap tiga tahun sekali, terungkap bahwa literasi sains peserta didik Indonesia dari berbagai tahun disajikan dalam Tabel 1. 
Tabel 1. Data Literasi Sains Siswa Indonesia dari Tahun 2000-2015

\begin{tabular}{lllllll}
\hline Tahun & 2000 & 2003 & 2006 & 2009 & 2012 & 2015 \\
\hline Skor & 393 & 395 & 393 & 383 & 375 & 403 \\
\hline Peringkat & $38 / 41$ & $38 / 40$ & $50 / 57$ & $60 / 65$ & $64 / 65$ & $64 / 75$ \\
\hline (Sumber: Kompas, 2017) & & & & &
\end{tabular}

Berdasarkan hasil penelitian literasi sains pada Tabel 1 yang telah diadakan oleh PISA (Programme for Internasional Students Assesment), tergambar bahwa kemampuan peserta didik Indonesia dalam bersaing di tingkat Internasional masih perlu ditingkatkan. Bahkan dalam beberapa periode terakhir, Indonesia menempati posisi di bawah negara-negara lain. Hal ini menunjukkan bahwa kemampuan literasi sains peserta didik di Indonesia masih sangat rendah bila dibandingkan dengan negara-negara lain.

Pada tingkat sekolah dasar, pembelajaran IPA atau sains merupakan salah satu pembelajaran yang menduduki peranan yang sangat penting karena sains dapat memberikan bekal peserta didik dalam menghadapi kemajuan ilmu pengetahuan dan teknologi dalam era abad 21. Oleh sebab itu, pembelajaran IPA yang ada di sekolah-sekolah diharapkan mampu menerapkan atau mengimplementasikan literasi sains dalam pembelajaran. Sains pada hakikatnya adalah suatu produk, proses, sikap dan teknologi. Sehingga dalam pembelajaran IPA, tidak mungkin peserta didik hanya memperoleh pengetahuan saja (produk) melainkan peserta didik harus terlibat aktif dalam pembelajaran seperti menemukan sesuatu pengetahuan, membuktikan pengetahuan tersebut melalui suatu praktikum atau percobaan dan menyimpulkannya dan pada akhirnya dapat menciptakan suatu alat atau teknologi yang nantinya dapat menyelesaikan masalah-masalah yang dihadapi oleh masyarakat.

Banyak faktor yang dapat mempengaruhi rendahnya literasi sains peserta didik. Salah satu faktor yang menyebabkan rendahnya kemampuan literasi sains adalah pemilihan sumber belajar. Hal ini sejalan dengan hasil penelitian yang dilakukan oleh Irawan (Ashri \& Hasanah, 2015) yaitu salah satu faktor penyebab rendahnya literasi sains peserta didik yang berkaitan langsung dan dekat dengan peserta didik adalah pemilihan sumber belajar. Di Indonesia, literasi sains dalam pembelajaran IPA sebagian besar masih terbatas pada materi buku ajar atau teks saja dari pada melakukan pembelajaran langsung. Stake \& Easly (Aqil, 2018) menyatakan bahwa buku pelajaran digunakan oleh $90 \%$ dari semua guru sains dan $90 \%$ dari alokasi waktu pembelajaran. Sehingga dapat disimpulkan bahwa pembelajaran literasi sains lebih berpusat pada guru dan metode yang digunakan oleh guru juga tidak jauh dari metode ceramah. Hal ini menyebabkan pelajaran sains terasa berat dan membosankan yang pada akhirnya peserta didik kurang memahami pembelajaran. Pengetahuan dan penerapan literasi sains yang hanya mengandalkan buku ajar atau teks belum sepenuhnya menyentuh jiwa peserta didik. Metode ceramah yang digunakan juga kurang relevan yang menyebabkan peserta didik hanya menjadi pendengar yang pasif. Apabila hal itu dilanjutkan, kelak peserta didik tidak akan dapat bersaing di era abad 21.

Pada literasi sains, pembelajaran dapat dilakukan dengan metode yang interaktif, inovatif, kreatif dan menyenangkan. Salah satu cara yang dapat dilakukan oleh guru untuk menerapkan literasi sains dalam pembelajaran yaitu dengan memanfaatkan lingkungan sebagai sumber belajar. Dengan memanfaatkan lingkungan, peserta didik diajak untuk melakukan pengamatan dan kegiatan ilmiah sederhana karena peserta didik dapat berinteraksi langsung serta memanfaatkan lingkungan sebagai sumber belajar. Melalui pembelajaran dan pengamatan sederhana langsung di alam, tujuan dari pembelajaran literasi sains dapat diserap secara sempurna. Disamping itu, peserta didik dapat pula mengidentifikasi pertanyaan, memperoleh pengetahuan baru, menjelaskan fenomena ilmiah dan mengambil kesimpulan berdasarkan apa yang mereka amati secara langsung.

\section{KAJIAN PUSTAKA Hakikat Sains dan Pembelajaran Sains}

Sains dalam arti sempit merupakan disiplin ilmu yang terdiri dari physical sciences (ilmu fisik) dan life sciences (ilmu biologi). Yang termasuk physical sciences adalah ilmu-ilmu astronomi, kimia, geologi, mineralogi, meteorologi, dan fisika, sedangkan life science meliputi anatomi, fisiologi, zoologi, citologi, embriologi, mikrobiologi. Hakikat Sains menurut Mawardi \& Mariati (Niswatuzzahro, Fakhriyah, \& Rahayu, 2018) adalah ilmu yang mempelajari gejala-gelaja alam dengan menggunakan 
metode ilmiah yang digunakan untuk memecahkan masalah ilmiah. Carin (1985) mendefinisikan Sains sebagai sistem pengetahuan alam semesta melalui pengumpulan data yang dilakukan dengan observasi dan eksperimen. Hakikat sains adalah pengetahuan tentang epistmologi (metode) dari sains, proses terjadinya sains, nilai dan keyakinan yang melekat untuk mengembangkan sains (Khalik dalam Yuliati, Latifah, Pendidikan, Universitas, \& Malang, 2017). Menurut Poedjiadi (Nofiana \& Julianto, 201) sains merupakan ilmu pengetahuan tentang objek dan fenomena alam yang diperoleh pemikiran dan penelitian para ilmuwan yang dilakukan melalui keterampilan bereksperimen dengan menggunakan metode ilmiah.

Berdasarkan pendapat tersebut dapat disimpulkan bahwa Sains merupakan suatu kumpulan pengetahuan yang mempelajari gejala-gejala alam yang tersusun secara sistematis, diperoleh dari suatu pemikiran dan penelitian melalui proses keterampilan observasi dan bereksperimen.

Sains membahas tentang gejala-gejala alam yang disusun secara sistematis yang didasarkan pada hasil percobaan dan pengamatan yang dilakukan oleh manusia. Hal ini sebagaimana yang dikemukakan oleh Powler (Winaputra, 1992) bahwa Sains merupakan ilmu yang berhubungan dengan gejala-gejala alam dan kebendaan yang sistematis yang tersusun secara teratur, berlaku umum yang berupa kumpulan dari hasil obervasi dan eksperimen. Pada hakikat ini, Sains ada empat macam yaitu sebagai produk, proses, sikap dan teknologi.

Sains sebagai produk yang mencakup fakta, konsep, prinsip, hukum, dan teori. Pada tingkat dasar sains dibedakan menjadi tiga, yaitu ilmu biologi (life science) yang mempelajari tentang kehidupan makhluk hidup meliputi anatomi, fisiologi, zoologi, citologi, embriologi, mikrobiologi contohnya adalah siswa mempelajari tentang salah satu sifat air yang dapat mengalir dari tempat tinggi ke tempat yang lebih rendah dan mendeskripsikan cara penggunaan air secara baik dan benar di sekolah maupun di rumah. Ilmu fisik (physical sciences) yang mempelajari tentang astronomi, kimia, geologi, mineralogi, meteorologi, dan fisika.Sedangkan ilmu bumi, mempelajari tentang benda-benda langit dan bumi.Dengan mempelajari ketiganya yaitu ilmu biologi, ilmu fisik, dan ilmu bumi siswa dapat melestarikan, melindungi dan mempergunakannya secara bijaksana berkaitan dengan lingkungan sekitar.

Sains sebagai proses, disini sains tidak dipandang sebagai kata benda, kumpulan pengetahuan atau fakta untuk dihafalkan tetapi sebagai kata kerja untuk mencapai sesuatu. Peserta didik tidak hanya sebagai pendengar saja tetapi keaktifan peserta didik dan guru sebagai fasilitator yang membuat kelas menjadi lebih menyenangkan dan kondusif.Contohnya adalah peserta didik mempelajari air tidak hanya menghafalkan, tetapi peserta didik mempelajarinya melalui pengetahuan awal yaitu pengamatan dan percobaan, mengumpulkan data dari pengukuran dan menghitung jumlah penggunaan air di sekolah setiap hari, setiap minggu, bahkan setiap tahun ajaran. Mendiskusikan dengan peserta didik lain sehingga pengetahuan baru diperoleh dari kesulitan tanpa menghafalkan yang belum tentu dapat diingat terus.

Sains sebagai sikap yaitu memotivasi peserta didik untuk mengembangkan pentingnya mencari jawaban dan penjelasan rasional tentang fenomena alam dan fisik serta melibatkan dalam aktivitas pembelajaran. Apabila sains diajarkan menurut cara yang tepat, maka sains merupakan suatu mata pelajaran yang memberikan kesempatan berpikir kritis. Hal ini dihadapkan pada suatu masalah seperti dapat dikemukakan suatu masalah atau perumusan masalah kemudian memecahkannya.

Sains sebagai teknologi merupakan pelaksanaan pembelajaran Sains untuk peserta didik dapat mempelajari kehidupan nyata, mengidentifikasi masalah, dan memanfaatkan teknologi.Sains berupaya membangkitkan minat manusia agar mau meningkatkan kecerdasan dan pemahamannya tentang alam seisinya yang penuh dengan rahasia yang tidak ada habisnya. Dengan tersingkapnya tabir rahasia alam itu satu persatu, serta mengalirnya informasi yang dihasilkannya, jangkauan sains semakin luas dan lahirlah sifat terapannya, yaitu teknologi adalah lebar. Namun dari jarak tersebut semakin lama semakin sempit, sehingga semboyan "Sains hari ini adalah teknologi hari esok" merupakan semboyan yang berkali-kali dibuktikan oleh sejarah. Bahkan kini Sains dan teknologi manunggal menjadi budaya ilmu pengetahuan dan teknologi yang saling mengisi (komplementer), ibarat mata uang, yaitu satu sisinya mengandung hakikat Sains (the nature of Science) dan sisi yang lainnya mengandung makna teknologi (the meaning of technology). Bahwa sains berfaedah bagi suatu bangsa.

Dari uraian di atas dapat disimpulkan bahwa dalam belajar sains harus mencakup empat komponen yaitu sains sebagai produk, proses, sikap, dan teknologi.Keempat komponen di atas, saling berkaitan dan saling mempengaruhi. Pembelajaran akan lebih bermakna apabila siswa diberi 
kesempatan untuk tahu dan terlibat secara aktif dalam menemukan konsep dari fakta-fakta yang dilihat dengan pengamatan dan percobaan serta mempelajari dari lingkungan sekitar dengan bimbingan guru yang hanya sebagai fasilitator.

\section{Literasi Sains}

Secara harfiah, literasi sains terdiri dari kata yaitu literatus yang berarti melek huruf dan scientia yang diartikan memiliki pengetahuan. Literasi sains dapat diartikan sebagai pengetahuan dan kecakapan ilmiah untuk mampu mengidentifikasi pertanyaan, memperoleh pengetahuan baru, menjelaskan fenomena ilmiah, serta mengambil simpulan berdasar fakta, memahami karakteristik sains, kesadaran bagaimana sains dan teknologi membentuk lingkungan alam, intelektual, dan budaya, serta kemauan untuk terlibat dan peduli terhadap isu-isu yang terkait sains (OECD, 2016). National Research Council (Depdikbud, 2017) menyatakan bahwa rangkaian kompetensi ilmiah yang dibutuhkan pada literasi sains mencerminkan pandangan bahwa sains adalah ansambel dari praktik sosial dan epistemik yang umum pada semua ilmu pengetahuan, yang membingkai semua kompetensi sebagai tindakan.

Literasi sains menurut PISA diartikan sebagai " the capacity to use scientific knowledge, to identify questions and to draw evidence-based conclusions in order to understand and help make decisions about the natural world and the changes made to it through human activity". Menurut Elsy Zuriyani (2017), literasi sains adalah suatu ilmu pengetahuan dan pemahaman mengenai konsep dan proses sains yang akan memungkinkan seseorang untuk membuat suatu keputusan dengan pengetahuan yang dimilikinya, serta terlibat dalam hal kenegaraan, budaya, dan pertumbuhan ekonomi. Holcon (Rahmania, Miarsyah, \& Sartono, 2015) menyebutkan bahwa literasi sains merupakan tujuan akhir dari pendidikan sains dengan kata lain pembelajaran sains diberikan kepada peserta didik dengan tujuan untuk membentuk peserta didik yang berliterasi sains.

Berdasarkan beberapa pendapat di atas maka dapat disimpulkan bahwa literasi sains adalah kemampuan, kecakapan, kompetensi yang dimiliki oleh peserta didik dalam menggunakan pengetahuan dan pemahaman mengenai konsep dan proses sains untuk mengidentifikasi, memperoleh pengetahuan baru, menjelaskan fenomena ilmiah, serta mengambil simpulan yang berkenaan dengan alam berdasarkan perubahan alam melalui aktivitas manusia.

Tujuan seorang pendidik mengembangkan literasi sains peserta didiknya untuk meningkatkan (Kusuma dalam Pertiwi, Atanti, \& Ismawati, 2018): 1) pengetahuan dan penyelidikan Ilmu Pengetahuan Alam 2) kosa kata lisan dan tertulis yang diperlukan untuk memahami dan berkomunikasi ilmu pengetahuan dan 3) hubungan antara sains, teknologi, dan masyarakat.

Oleh karena itu, dengan adanya literasi sains dalam pembelajaran, siswa-siswi diharapkan memiliki kemampuan yang harus dimiliki yaitu: a) memiliki kemampuan pengetahuan dan pemahaman tentang konsep ilmiah dan proses yang diperlukan untuk berpartisipasi dalam masyarakat di era digital, b) kemampuan mencari atau menentukan jawaban pertanyaan yang berasal dari rasa ingin tahu yang berhubungan dengan pengalaman sehari-hari, c) memiliki kemampuan, menjelaskan dan memprediksi fenomena. d) dapat melakukan percakapan sosial yang melibatkan kemampuan dalam membaca dalam mengerti artikel tentang Ilmu pengetahuan; e) dapat mengindentifikasi masalah-masalah ilmiah dan teknologi informasi; f) memiliki kemampuan dalam mengevaluasi informasi ilmiah atas dasar sumber dan metode yang dipergunakan; g) dapat menarik kesimpulan dan argument serta memiliki kapasitas mengevaluasi argument berdasarkan bukti. Untuk mengukur tingkat kemampuan literasi sain, diperlukan penilaian literasi sains tersebut.

Penilaian literasi sains menurut (Kusuma Astuti, 2016) yaitu menilai pemahaman peserta didik terhadap konten sains, proses sains, dan konteks aplikasi sains. Konten dalam literasi sains meliputi materi yang terdapat dalam kurikulum dan materi yang bersifat lintas kurikulum dengan penekanan pada pemahaman konsep dan kemampuan untuk menggunakannya dalam kehidupan. Proses sains merujuk pada proses mental yang terlibat ketika peserta didik memecahkan permasalahan. Sedangkan konteks adalah area aplikasi dari konsep-konsep sains. Sesuai dengan pandangan tersebut, penilaian literasi sains tidak semata-mata berupa pengukuran tingkat pemahaman terhadap pengetahuan sains tetapi juga pemahaman terhadap berbagai aspek proses sains serta kemampuan mengaplikasikan pengetahuan dan proses sains dalam situasi nyata yang dihadapi peserta didik, ini berarti bahwa penilaian literasi sains tidak hanya berorientasi pada penguasaan materi sains akan tetapi juga pada penguasaan kecakapan hidup, kemampuan berpikir dan kemampuan dalam melakukan proses-proses sains pada kehidupan nyata peserta didik. 


\section{Media Pembelajaran Literasi Sains}

Pembelajaran literasi sains merupakan bagian terpenting dalam penentuan ketercapaian pendidikan IPA di sekolah. Tentunya harus diiringi dengan proses pembelajaran yang interaktif, inspiratif, menyenangkan, menantang, dan dapat memotivasi peserta didik untuk berpartisipasi aktif dalam proses pembelajaran (Hidayati \& Julianto, 2018). Pembelajaran yang menitik beratkan pada literasi sains adalah pembelajaran yang sesuai dengan hakikat IPA yang mana tidak hanya berorientasi pada pengetahuan saja melainkan juga pada proses terintegrasinya konsep dan pengamalan serta ketercapaian dari sikap ilmiah.

Oleh sebab itu, penerapan literasi sains harus diimbangi dengan pembelajaran inquiry ilmiah untuk menumbuhkan kemampuan berpikir kritis pada peserta didik agar mampu menyelesaikan segala persoalan yang ada sehingga peserta didik akan memperoleh pemahaman yang lebih mendalam terhadap alam sekitar.

Selain proses pembelajaran, media juga bagian dari tercapainya literasi sains di sekolah dasar. Karena dengan adanya media yang inovatif, dan menarik bagi peserta didik maka peserta didik juga akan tertarik untuk menerapkan literasi sains.

Apabila dilihat dari karakteristik peserta didik sekolah dasar berada pada tahap berpikir operasional konkrit. Oleh sebab itu, guru harus dapat memilih media konkrit yang sesuai untuk diterapkan berdasarkan kondisi dan kebutuhan peserta didik sehingga peserta didik dapat menerima dan memahami pengetahuan yang didapatkan. Hal ini menunjukkan ketercapaian dalam pembelajaran literasi sains.

Lingkungan sebagai media sekaligus sumber pembelajaran Berdasarkan Kamus Umum Bahasa Indonesia (KUBI) lingkungan diartikan sebagai bulatan yang melingkungi (melingkari). Pengertian lainnya yaitu sekalian yang terlingkung di suatu daerah. Literatur lain menyebutkan bahwa lingkungan itu merupakan kesatuan ruang dengan semua benda dan keadaan makhluk hidup termasuk di dalamnya manusia dan perilakunya serta makhluk hidup lainnya. Menurut Supardi (2003), lingkungan atau sering juga disebut lingkungan hidup adalah jumlah semua benda hidup dan benda mati serta seluruh kondisi yang ada di dalam ruang yang kita tempati. Pengertian lingkungan menurut Danusaputro (1985) lingkungan hidup adalah semua benda dan daya serta kondisi, termasuk di dalamnya manusia dan tingkah perbuatannya, terdapat dalam ruang dimana manusia berada dan mempengaruhi kelangsungan hidupnya serta kesejahteraan manusia. Pengertian lingkungan menurut Soemarwoto (2001) ialah ruang yang ditempati suatu makhluk hidup bersama dengan benda hidup dan tak hidup di dalamnya tumbuhan, hewan, manusia dan jasad renik menempati ruang tertentu. Dari beberapa definisi diatas dapat disimpulkan bahwa lingkungan adalah suatu kesatuan ruang yang ditempati oleh makhluk hidup yang di dalamnya terdapat benda hidup dan benda tak hidup.

\section{METODE PENELITIAN}

Jenis penelitian ini adalah penelitian deskriptif. Adapun metode yang digunakan dalam penelitian ini adalah literature review. Data diperoleh dari mentelaah artikel, jurnal maupun sumbersumber yang lain yang berkaitan dengan penelitian kemudian disimpulkan. Pengolahan dan analisis data dilakukan secara kualitatif dan kumulatif dengan penjabaran deskriptif.

\section{HASIL PENELITIAN DAN PEMBAHASAN Pembelajaran Literasi Sains melalui Pemanfaatan Lingkungan}

Literasi sains dapat diartikan sebagai pengetahuan dan kecakapan ilmiah untuk mampu mengidentifikasi pertanyaan, memperoleh pengetahuan baru, menjelaskan fenomena ilmiah, serta mengambil simpulan berdasar fakta, memahami karakteristik sains, kesadaran bagaimana sains dan teknologi membentuk lingkungan alam, intelektual, dan budaya, serta kemauan untuk terlibat dan peduli terhadap isu-isu yang terkait sains. Dalam pembelajaran IPA, guru dapat memanfaatkan lingkungan untuk menerapkan literasi sains. Dalam pemanfaatan lingkungan, guru membawa kegiatan pembelajaran yang biasanya dilakukan di dalam kelas oleh guru dan peserta didik ke realitas yang lebih nyata yaitu lingkungan. Artinya bahwa melalui pembelajaran dengan memanfaatkan lingkungan sebagai sumber belajar, peserta didik diajak untuk memahami konsep, menerapkan konsep, memecahkan masalah hingga menyimpulkan suatu permasalahan dengan melibatkan lingkungan 
sekitar yang dekat dengan peserta didik. Dengan demikian peserta didik akan lebih memahami pembelajaran dan menghindari kejenuhan.

Berikut ini adalah research gap dari penelitian sebelumnya tentang hasil literasi sains melalui pemanfaatan lingkungan, dapat dilihat tabel berikut.

Tabel 2. Ketuntasan Hasil Belajar Literas Sains Melalui Pemanfaatan Lingkungan

\begin{tabular}{|c|c|c|c|c|c|c|c|c|}
\hline \multirow[b]{2}{*}{ Tindakan } & \multirow[b]{2}{*}{ Siklus I } & \multicolumn{3}{|c|}{ Banyaknya siswa } & \multirow[b]{2}{*}{$\begin{array}{l}\text { Siklus } \\
\text { II }\end{array}$} & \multicolumn{3}{|c|}{ Banyaknya siswa } \\
\hline & & Tuntas & $\begin{array}{l}\text { Tidak } \\
\text { tuntas }\end{array}$ & Jumlah & & Tuntas & $\begin{array}{l}\text { Tidak } \\
\text { tuntas }\end{array}$ & Jumlah \\
\hline Pretes & $46,2 \%$ & 12 & 14 & 26 & $69,2 \%$ & 18 & 8 & 26 \\
\hline Postes & $69,2 \%$ & 18 & 8 & 26 & $88,5 \%$ & 23 & 3 & 26 \\
\hline
\end{tabular}

(sumber: Nurhayati, 2018)

Dari Tabel 2, menunjukkan bahwa kemampuan literasi sains peserta didik semakin meningkat melalui pemanfaatan lingkungan sebagai sumber belajar. Kemampuan literasi sains peserta didik dari hasil pretes siklus I adalah 46,2\% dan dari hasil postes siklus I meningkat menjadi $69,2 \%$. Sedangkan dari hasil pretes dan postes pada siklus II, kemampuan literasi peserta didik meningkat dari 69,2\% menjadi $88,5 \%$. Pembelajaran yang dilakukan oleh Nurhayati menggunakan pendekatan Discovery Learning pada materi pokok lingkungan. Dalam penelitian ini, lingkungan dijadikan sumber belajar peserta didik.

Selain penelitian yang telah dilakukan oleh Nurhayati pada tahun 2018, penelitian lain juga dilakukan oleh (Fitriani et al., 2018) terhadap kemampuan literasi sains mahasiswa pada mata kuliah botani.

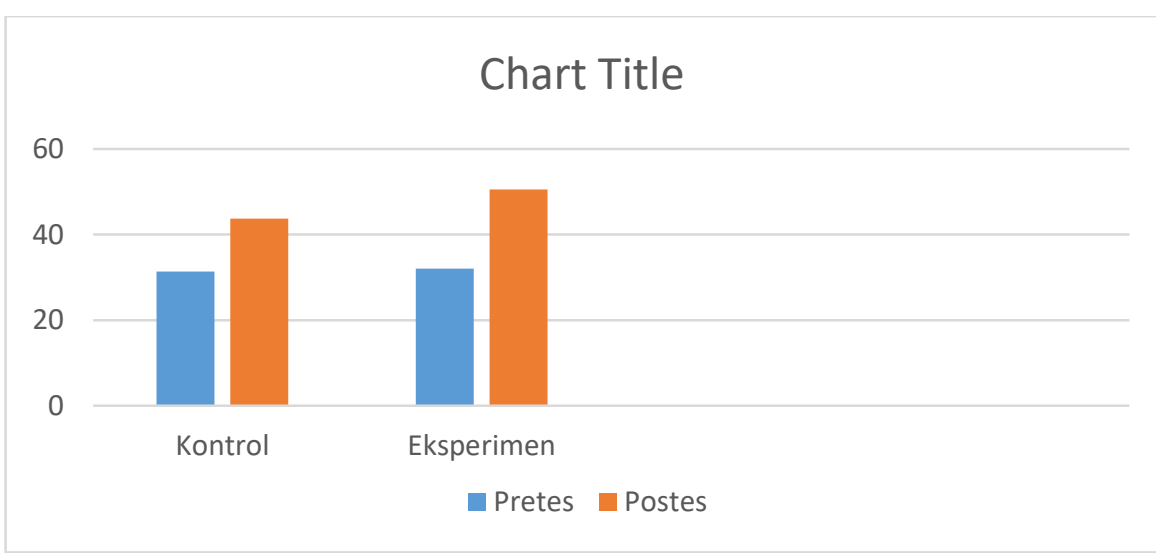

Gambar 1. Grafik skor literasi sains kelas kontrol dan eksperimen

Berdasarkan grafik di atas, diketahui adanya perbedaan skor literasi sains pretes dan postes untuk kelas kontrol dan eksperimen. Kelas eksperimen memiliki skor rata-rata yang lebih tinggi dibandingkan kelas kontrol. Hal ini terjadi karena proses pembelajaran yang berbasis lingkungan pada kelas eksperimen melibatkan mahasiswa secara aktif dalam pembelajaran. Mahasiswa dituntut untuk melaksanakan kegiatan pembelajaran dengan menggunakan metode ilmiah.

Dari beberapa penelitian yang telah dilakukan melalui pemanfaatan lingkungan, dapat disimpulkan bahwa pemanfaatan lingkungan tepat digunakan untuk menumbuhkan dan mengembangkan pembelajaran literasi sains.

\section{Pelaksanaan Pembelajaran Literasi Sains Melalui Pemanfaatan Lingkungan}

Hewitt et al (Situmorang, 2017) mendefinisikan IPA sebagai bentuk keterpaduan bidang biologi, fisika, kimia, dan bilogi yang dikaitkan melalui masing-masing konsep yang terkadung dalam masing-masing bidang. Penyajian dilakukan melalui tema umum dan membahas berbagai topik permasalahan yang berkaitan dengan kehidupan sehari-hari. Literasi sains dengan memanfaatkan lingkungan menurut Munasya (2018), dapat diterapkan pada materi tentang makhluk hidup dan proses kehidupannya. Pada materi ini, peserta didik diajak untuk mengamati ciri-ciri makhluk hidup yang dilihatnya, apa saja kebutuhan mereka, dimana habitatnya dan lain sebagainya. Hasil pengamatan ditulis dan dicocokkan dengan materi pelajaran yang sedang dipelajari. Setelah melakukan pengamatan, 
peserta didik juga dapat melakukan percobaan untuk membuktikan konsep yang tertera dalam buku. Pengamatan sederhana tidak hanya bisa dilakukan pada materi makhluk hidup saja, namun bisa juga merambah pada materi lain seperti gaya, ekosistem, energi perubahan wujud, dan lain sebagainya. Semua hal yang berhubungan dengan literasi sains dapat dipelajari melalui pengamatan sederhana.

Pembelajaran menggunakan lingkungan sebagai sumber belajar dikenal dengan pendekatan lingkungan. Menurut Mulyasa (Ernawulan, 2015) pembelajaran literasi sains melalui pendekatan lingkungan dapat dilakukan dengan cara: a) Membawa peserta didik ke lingkungan untuk kegiatan pembelajaran; dan b) Membawa sumber-sumber dari lingkungan ke sekolah untuk kepentingan pembelajaran.

\section{Manfaat Lingkungan Sebagai Sumber Belajar untuk Pembelajaran Literasi Sains}

Memanfaatkan lingkungan sebagai sumber pembelajaran memiliki banyak keuntungan. Beberapa keuntungan memanfaatkan lingkungan sebagai sumber belajar menurut Netty Demak H. Sitanggang \& Niken Hermawati (2015) antara lain: a) menghemat biaya, karena memanfaatkan bendabenda yang telah ada di lingkungan; b) memberikan pengalaman yang riil kepada peserta didik, pelajaran menjadi lebih konkrit, tidak verbalistik; c) karena benda-benda tersebut berasal dari lingkungan peserta didik, maka benda-benda tersebut akan sesuai dengan karakteristik dan kebutuhan peserta didik, sesuai dengan konsep pembelajaran kontekstual (contextual learning); d) pelajaran lebih aplikatif, materi belajar yang diperoleh peserta didik melalui media lingkungan kemungkinan besar akan dapat diaplikasikan langsung, karena peserta didik akan sering menemui benda-benda atau peristiwa serupa dalam kehidupannya sehari-hari; e) dengan media lingkungan, peserta didik dapat berinteraksi secara langsung dengan benda, lokasi atau peristiwa sesungguhnya secara alamiah; dan f) lebih komunikatif, sebab benda dan peristiwa yang ada di lingkungan peserta didik biasanya mudah dicerna oleh peserta didik, dibandingkan dengan media yang dikemas (didesain).

Pembelajaran dengan memanfaatkan lingkungan sebagai sumber belajar adalah pembelajaran yang bersifat kontekstual. Pembelajaran kontekstual menurut Hosnan (2014) adalah konsep belajar yang mana guru menghadirkan dunia nyata ke dalam kelas dan membimbing peserta didik membuat hubungan keterkaitan antara pengetahuan yang ia miliki dengan penerapannya dalam kehidupan seharihari, namun peserta didik memperoleh pengetahuannya tidak secara langsung banyak tetapi bertahap terbatas dari pengkonstriksian sendiri sebagai bekal untuk memecahkan masalah dalam kehidupan sehari-hari.

Kelebihan pembelajaran menggunakan pendekatan lingkungan (Ernawulan, 2015) sebagai berikut: a) menghemat biaya karena memanfaatkan benda-benda yang telah ada di lingkungan; b) praktis dan mudah dilakukan; c) memberikan pengalaman yang riil kepada peserta didik, pelajaran menjadi lebih kongkrit, tidak verbalistik; d) karena benda-benda tersebut berasal dari lingkungan, benda-benda tersebut sesuai dengan karakteristik dan kebutuhan peserta didik; e) pelajaran lebih aplikatif, maksudnya materi pelajaran yang dipeoleh peserta didik melalui media lingkungan kemungkinan besar akan dapat diaplikasikan langsung, karena peserta didik akan menemui bendabenda tersebut dalam kehidupan sehari-hari; f) media lingkungan memberikan pengalaman langsung kepada peserta didik; dan g) lebih komunikatif karena peristiwa dan benda yang yang ada di lingkungan peserta didik biasanya lebih mudah dicerna oleh peserta didik dibandingkan media pembelajaran yang dikemas.

\section{SIMPULAN DAN SARAN}

Dalam era abad 21, literasi sains dalam pembelajaran IPA memegang peranan yang sangat penting karena mempersiapkan peserta didik yang berkualitas, handal, dan mampu berkompetisi dengan dunia internasional. Untuk dapat menciptakan dan mengembangkan literasi sains dalam pembelajaran IPA, guru perlu menciptakan kondisi belajar yang melibatkan keaktifan peserta didik. Pembelajaran yang hanya didominasi oleh guru melalui metode ceramah dan buku ajar, hanya mengakibatkan peserta didik menjadi pendengar yang pasif dan menimbulkan kejenuhan bagi peserta didik. Kejenuhan inilah yang nantinya akan membuat peserta didik tidak memiliki penalaran dan pengetahuan tentang literasi sains.

Pembelajaran literasi sains dengan memanfaatkan lingkungan, membawa peserta didik melakukan kegiatan di luar kelas melalui pengamatan langsung. Melalui pengamatan langsung dengan lingkungan, peserta didik dapat mengidentifikasi pertanyaan, melalukan percobaan dan menyimpulkan 
percobaan berdasarkan apa yang mereka amati. Lingkungan membantu peserta didik untuk belajar secara nyata (kontekstual) dan merealisasikan hal-hal yang dipelajari di dalam buku ajar atau teks. Pembelajaran literasi sains dengan memanfaatkan lingkungan, dapat diterapkan dalam semua materi sains baik itu materi tentang makhluk hidup, kalor, gaya dan sebagainya. Dengan memanfaatkan lingkungan sebagai sumber belajar sains, peserta didik akan memiliki pemahaman yang lebih baik tentang literasi sains.

Dari simpulan yang ada, maka saran yang dapat diberikan sebagai bahan pertimbangan penelitian selanjutnya adalah: 1) guru harus mampu memilih dan menetukan kriteria yang tepat dalam memanfaatkan lingkungan sebagai sumber belajar literasi sains. Pemilihan sumber belajar yang tidak tepat, akan menyebabkan pembelajaran menjadi tidak efektif. Hal ini akan mengakibatkan rendahnya kemampuan literasi sains peserta didik; 2) selain memanfaatkan lingkungan sebagai sumber belajar literasi sains, guru harus membuat dan mengembangkan Lembar Kerja Peserta Didik (LKPD) sehingga dalam pembelajaran peserta didik terlibat aktif. Dengan keaktifan inilah kemampuan literasi sains peserta didik akan semakin meningkat; dan 3) pembelajaran literasi sains melalui pemanfaatan lingkungan dapat dilakukan dengan berbagai metode, model ataupun pendekatan pembelajaran. Menggunakan lingkungan sebagai sumber belajar tanpa diimbangi dengan metode, model dan pendekatan pembelajaran yang tepat akan menyebabkan pembelajaran literasi sains menjadi sia-sia.

\section{UCAPAN TERIMAKASIH}

Dalam penyusunan artikel ini, penyusun mengucapkan terima kasih terhadap pihak-pihak yang sangat membantu dalam penyusunan dan pembuatan artikel diantaranya:

1. Allah SWT, sehingga saya senantiasa diberi kesehatan dalam menyusun artikel penelitian

2. Dr. Agung Purwanto, M.Si, selaku dosen pembimbing mata kuliah Kajian Praktikum IPA Sekolah Dasar Berorientasi Lingkungan

3. Orangtua dan keluarga yang telah memberi banyak dukungan dalam penyusunan artikel

4. Teman-teman Pascasarjana Universitas Negeri Jakarta

5. Serta pihak-pihak lain yang tidak dapat saya sebutkan satu-persatu

\section{DAFTAR PUSTAKA}

Aqil, D. I. (2018). Literasi Sains Sebagai Konsep Pembelajaran Buku Ajar Biologi di Sekolah. Wacana Didaktika, 5(02), 160-171. https://doi.org/10.31102/wacanadidaktika.5.02.160-171

Ashri, N., \& Hasanah, L. (2015). Pengembangan Bahan Ajar Ipa Terpadu Tema Udara. Prosiding Simposium Nasional Inovasi Dan Pembelajaran Sains 2015 (SNIPS 2015), 2(1), 469-472.

Carin, A.A. (1985). Teaching Modern Science. London: Bell \& Howell Company

Danusaputro, Munajat. (1985). Hukum Lingkungan, Buku I Umum. Jakarta

Depdikbud. (2017). Materi Pendukung Literasi Sains. Jakarta : Depdikbud

Ernawulan. (2017). Membangun Imajinasi dan Kreatifitas Anak Melalui Literasi. Prosiding Seminar Nasional Pendidikan Dasar Volume 2 SPS UPI 2015

Fitriani, R., Putra, R. R., Biologi, P., Siliwangi, U., Sains, L., \& Phanerogamae, B. (2018). Pembelajaran Berbasis Lingkungan untuk Mengembangkan Literasi Sains Mahasiswa pada Mata Kuliah Botani Phanerogamae. 83-86

H, Netty Demak., Sitangggang \& Niken Hermawati. (2015). Peningkatan Motivasi Belajar Tumbuhan Melalui Pemanfaatan Lingkungan Sebagai Sumber Belajar. Jurnal Ilmiah Kependidikan. 2 (3), 207-222.

Hidayati, Fitria., Julianto. (2018). Penerapan Literasi sains dalam Pembelajaran IPA di Sekolah Dasar untuk Meningkatkan Kemampuan Berpikir Kritis Siswa dalam Memecahkan Masalah. Journal Seminar Nasional Pendidikan.

Hosnan. (2014). Pendekatan Saintifik dan Kontekstual dalam Pembelajaran Abad 21. Bogor: Ghalia Indonesia 
Karuni, Ditya Wiyana. (2017). Pentingnya Menerapkan Literasi Sains dalam Pembelajaran IPA di Sekolah Dasar. https://dityawiyana28.wordpress.com/2017/01/12/uas-telaah-kurikulum-ipa$\mathrm{smp} /$

Kusuma Astuti, Y. (2016). Literasi Sains Dalam Pembelajaran IPA. Issn, 7(3B), 1693-7945. Retrieved from http://ejournal.unwir.ac.id/file.php?file=preview_jurnal\&id=735\&cd=0b2173ff6ad6a6fb09c95f6d50001df6\&name=8. Yani Kusuma Astuti STKIP NU INDRAMAYU_GW _Juni_2016.pdf

Munasya. (2018). Pembelajaran Literasi Sains untuk Anak-anak. Retrieved from http://munasya.com/pembelajaran-literasi-sains-untuk-anak-anak/.

Niswatuzzahro, V., Fakhriyah, F., \& Rahayu, R. (2018). Penerapan Model Discovery Learning Berbantuan Media Audio Visual untuk Meningkatkan Literasi Sains Siswa Kelas 5 SD. Scholaria: Jurnal Pendidikan Dan Kebudayaan, 8(3), 273-284. https://doi.org/10.24246/j.js.2018.v8.i3.p273-284.

Nurhayati. (2018). Peningkatan Kemampuan Literasi Sains dan Hasil Belajar Siswa Pada Pokok Bahasan Lingkungan Dengan Menerapkan Pembelajaran Discovery Learning di Kelas VII SMP Negeri 2 Binjai. Jurnal Pelita Pendidikan, 6(4), 269-273.

Nofiana, M., \& Julianto, T. (2018). Upaya Peningkatan Literasi Sains Siswa Melalui Pembelajaran Berbasis Keunggulan Lokal. Biosfer: Jurnal Tadris Biologi, 9(1), 24. https://doi.org/10.24042/biosf.v9i1.2876

OECD.(2016). The PISA 2016 Assessment Framework. Paris: OECD.

Pertiwi, U. D., Atanti, R. D., \& Ismawati, R. (2018). Pentingnya Literasi Sains pada Pembelajaran IPA SMP Abad 21. Indonesian Journal of Natural Science Education (IJNSE), 01(01), 24-29. Retrieved from jom.untidar.ac.id/index.php/ijnse/index

Rahmania, S., Miarsyah, M., \& Sartono, N. (2015). Perbedaan kemampuan literasi sains siswa dengan gaya kognitif field independent dan field dependent. Biosfer: Jurnal Pendidikan Biologi, 8(2), 27-34.

Situmorang, R. P. (2017). Integrasi Literasi Sains Peserta Didik Dalam Pembelajaran Sains. Satya Widya, 32 (1), 49-59. https://doi.org/10.24246/j.sw.2016.v32.i1.p49-56

Soemarwoto, Otto. (2001). Ekologi, Lingkungan Hidup. Jakarta: Djembatan

Supardi,Bahrudin. (2003). Berbakti Untuk Bumi. Bandung: Rosdakarya

Riskawati, R., Yuliati, L., \& Latifah, E. (2017). Penguasaan Konsep dan Literasi Sains Siswa di Kelas X SMAN 11 Jeneponto. In Seminar Nasional Pendidikan IPA (Vol. 2).

Zuriyani, Elvi. (2017). Literasi Sains dan Pendidikan. http://www.academia.edu/11664935/literasisains-dan-pendidikan

Winataputra, U. 1992. Strategi Belajar Mengajar IPA. Jakarta : Universitas Terbuka 